\title{
Application of multiple-use indices to assess reservoirs water quality and the use of plankton community data for biomonitoring purposes
}

\begin{abstract}
In this study we applied and compared the results of different types of water quality indices for multipurpose uses, such as water supply, trophic levels evaluation and aquatic community's protection. The main aim is to generate new insights to improve the water quality monitoring programs and protocols used in local and regional scales. The selected indices were the Water Quality Index, the original Trophic State Index proposed by Carlson and three other derived models, as well as three biotic indices - the Phytoplankton Community Index, the Zooplankton Community Index and the Planktonic Index of Biotic Integrity. The study was carried out in eight reservoirs of a large tropical/subtropical watershed from Southeast Brazil: The reservoirs are arranged in a cascade system along the Paranapanema River. Thirty-seven sites were sampled in two seasons (dry and wet). The WQI ranged from "Good" to "Excellent" in agreement with previous limnological studies (predominantly low nutrients and chlorophyll values) and indicated the temporal dry-rain patterns. The original Carlson index overestimated the trophic levels while the modified indices for reservoirs seemed to be more suitable for tropical and subtropical environments, especially the one for tropical/subtropical reservoirs which was more sensitive to data variability. Results also demonstrate the great potential of using integrated plankton indices, mainly zooplankton metrics, as reliable environmental indicators.
\end{abstract}

Keywords: WQI, TSI, zooplankton, phytoplankton, monitoring programs protocols
Volume 2 Issue 2 - 2018

\author{
Juliana Pomari,' Douglas D Kane, ${ }^{2}$ Marcos G \\ Nogueira' \\ 'Department of Zoology, Biosciences Institute, São Paulo State \\ University (UNESP), Brazil \\ ${ }^{2}$ Natural Science and Mathematics Division, Defiance College, \\ USA
}

Correspondence: Juliana Pomari, São Paulo State University (UNESP), Department of Zoology, Biosciences Institute. Brazil, Email jupomari@ibb.unesp.br

Received: January 24, 2018| Published: March 26, 2018
Abbreviations: WQI, Water Quality Index; TSI, Trophic State Index; PCI, Phytoplankton Community Index; ZCI, Zooplankton Community Index; P-IBI, Planktonic Index of Biotic Integrity

\section{Introduction}

Reservoirs are complex ecological systems with multiple uses and exhibit a hierarchy of functions, mechanisms of feedback, regulation, and control. ${ }^{1}$ A strategy to evaluate and monitor such complex systems, at spatial and temporal scales, is the use of integrated indices and indicators based on selected abiotic factors or community indicators. Environmental indices and indicators emerged as result of the growing social concern for the environmental aspects related to socioeconomic development, a process that requires many information organized in distinct degrees of complexity. The main goal of indices is to assess the ecosystem present condition and follow trends over time. They can provide an early warning signal of changes in the environment and be used to diagnose the causes of the problems. ${ }^{2}$ Environmental indicators should represent key information about structure, function, and composition of the ecosystem. ${ }^{2}$ They need to capture the ecosystem complexities but remain simple enough to be easily and routinely monitored and have the following criteria: be easily measured, be sensitive to stresses on the system, respond to stress in a predictable manner, be anticipatory, predict changes that can be averted by management actions, be integrative, have a known response to disturbances, anthropogenic stresses, and changes over time, and have low variability in response. ${ }^{2}$ The most challenging problem on selection of environmental indices and indicators is to understand the fundamental principles of ecology, also the inherent complexity of environmental problems and the limitations of using just a single indicator or index that integrate information across a range of attributes and/or at different levels of biological organization. ${ }^{3,4}$ A comprehensive historical review and future perspectives - use of artificial intelligence, of water quality indices is provided by ${ }^{5}$ The authors firstly stated that the definition of the 'water quality' of a certain water body is not an easy task, much more complex than the definition of the water quantity, which can be expressed in terms of a single parameter (e.g. millions of $\mathrm{m}^{3}$ or $\mathrm{m}^{3} \mathrm{sec}^{-1}$ ). And more, water quality standard for what use? Thus, the Water Quality Indices (WQIs) have the challenge of 'measuring' water quality and communicate it to the water users. Appropriate water quality indices can be useful for management purposes - stakeholder's decision processes, improvement of monitoring protocols, and expansion of scientific knowledge, as well as to disseminate the results of the analyses to citizens. ${ }^{6}$ To make it possible is inherent to consider that a proper choice of an index or indicators must be intrinsically related to the studied environment and will often present such regional character, ${ }^{7}$ which means that they will probably need some adaptation, but always considering the fundamental assumptions and constrains. Another advantage of water quality indices is that they provide costeffective water quality assessment, which is particularly important for developing countries, ${ }^{8}$ as well as the possibility to overcome unbalanced spatial and temporal series of data. ${ }^{9,10}$ In São Paulo State, the most populous and industrialized in Brazil, the official environmental agency named CETESB (Companhia de Tecnologia de Saneamento Ambiental, in Portuguese), has monitored a large number of water bodies for almost three decades, always focusing on public supply requirements. Nevertheless, the federal legislation ${ }^{11}$ predicts 
a more comprehensive set of uses of surficial waters, including "to preserve the balance natural of aquatic communities". Therefore, it is important that the water quality monitoring programs also consider the biota composition and dynamics of the communities' structure.

According to, ${ }^{11}$ the Special Class of waters (the best natural condition) is destined:

a. To the supply for human consumption, with only simple disinfection procedure;

b. To preserve the natural balance of aquatic communities; and

c. To preserve the aquatic environments in official protected areas,

While Class 1 may be destined:

a. To the supply for human consumption after simplified treatment;

b. To protect aquatic communities;

c. To recreation of primary contact, such as swimming, water skiing and diving,

d. To irrigation of vegetables and fruits that grow on the ground and are eaten raw without film removal; and

e. To protection of aquatic communities in Indigenous lands. Classes 2, 3 and 4 (the worst condition) indicates progressive deterioration and restriction of uses.

Although there is not an ideal model to measure environmental impacts, there are available options for selection and development of indices and indicators. Additionally, more applied approaches have been requested by engineers and managers who work in the management of reservoirs, in order to complement the basic limnological studies performed by academic institutions. ${ }^{1}$ Based on studies carried out in the 1970's, which were supported by a panel of water quality experts, the National Sanitation Foundation of United States developed the Water Quality Index (WQI). The experts were argued about the variables to be evaluated and their relative importance, mainly focusing on contamination of the water bodies caused by the discharge of domestic sewage. The WQI is a widely accepted and commonly used in monitoring programs. ${ }^{5}$ Based on data of São Paulo State reservoirs, ${ }^{12}$ adapted and developed a regional WQI. The trophic state index (TSI) proposed by Carlson in the 1970 's for temperate lakes ${ }^{13}$ is also commonly used in ecological and monitoring programs. It is based on the empirical relationships among Chlorophyll $a(\mathrm{Chl} a$ ), Total Phosphorus (TP) and Secchi disk depth (SDD). This index has frequently been applied by researchers and government institutions to, indirectly, estimate the lake trophic status and indicate the excessive algal biomass. However, it is known that the relationships and the equations for calculating the index should be adapted when applied to aquatic systems with distinct ecological structure and functional patterns from those originally considered. Otherwise results of the index application can lead to misclassification of the trophic status. ${ }^{14}$

Brazilian researchers have proposed modifications of Carlson original model's based on the prediction that the trophic state may be more complex in tropical/subtropical freshwaters. That is because there are more environmental constraints controlling nutrient dynamics and phytoplankton responses in such water bodies. ${ }^{14}$ Modifications differ in the calculations, in the number of considered variables and in the weighting given to each one. Although the previously mentioned indices are widely recognized and used, in 1998, the Resolution Number 65 of the SMA (São Paulo State Environmental Secretary - Secretaria de Meio Ambiente, in Portuguese) ${ }^{15}$ established a working group to revise the Water Quality Index (WQI) aiming to include information on the aquatic biota and develop other assessment methods. The objective is to consider biological indicators integrated with trophic indices. The technical group, composed of experts from CETESB, Universities and Research Institutes, generated a first version for biological indices based on phytoplankton, zooplankton, benthos and fish communities. ${ }^{12}$ We selected for our study two of the proposed indices, the Phytoplankton Community Index for Reservoirs (FCI) and the Zooplankton Community Index for Reservoirs (ZCI). In this study we applied, and compared, different types of water quality indices considered to be appropriated for assessment of aquatic ecosystems for multipurpose uses (e.g. water supply, hydropower generation, aquaculture, recreation, irrigation, aquatic community's protection). Our case study is focused on the Paranapanema River Reservoir Cascade (Southeast Brazil). The following indices were selected: Water Quality Index (WQI), Trophic State Index (original and three regionally modified models), Phytoplankton Community Index (FCI), Zooplankton Community Index (ZCI) and the Planktonic Index of Biotic Integrity (P-IBI) - a new tool that has been recently developed (see Material and methods). The aim of the study is to get new insights on this subject, contributing for the evaluation and improvement of the regional (Southeast and South Brazil) water quality monitoring programs. Additionally, we present an exploratory analysis on zooplankton responses to water quality and trophic conditions variability in the selected reservoirs. Differently from phytoplankton, there is a lack of information correlating zooplankton and the distinct environment conditions. The perspective is to incorporate available academic information on practical protocols for environmental evaluation and management, as phytoplankton and zooplankton have been regularly sampled and analyzed as part of the regional water quality monitoring programs.

\section{Study area}

The Paranapanema River is the natural border between the States of Paraná and São Paulo (Southeast Brazil), with a length of $929 \mathrm{~km}$. Since the 1950's, a set of hydropower dams were constructed in the main course of the river. Limnological studies ${ }^{16-18}$ provided basic information about this reservoir cascade and since 2010 a regular Limnological and Water Quality Monitoring Program of has been executed in eight reservoirs. Three reservoirs, Jurumirim, Chavantes and Capivara, are storage systems (i.e. large size, high water retention times), whereas the others, Salto Grande, Canoas II, Canoas I, Taquaruçu and Rosana are run-of-the-river systems (smaller, rapid flow).$^{18}$ The selected reservoirs are arranged in a cascade (upstream $\rightarrow$ downstream) system and data were obtained at 37 sampling sites (Figure 1). The sampling design intended to cover the longitudinal gradient between the lotic (upstream) and lentic (dam) zones of each reservoir, as well as the entrance of important tributaries. At least three up to six sites in each reservoir were selected.

\section{Materials and methods}

Field work was carried out during wet/summer (March/2011) and dry/spring (October/2011) seasons. The Water Quality Index (WQI) was calculated using nine variables: water temperature, $\mathrm{pH}$, dissolved oxygen, biochemical oxygen demand, thermotolerant 
coliforms, total nitrogen, total phosphorus, total solids, and turbidity The methodologies concerning each individual variable (sampling and analysis) are detailed in ${ }^{19}$ The WQI calculation and classification followed, ${ }^{12}$ whose results can range from 0 to 100 (the higher the value the better the water quality) (Table 1). For the Trophic State Indices four variables were used: Secchi disc transparency, total phosphorus, reactive soluble phosphorus and chlorophyll $a$. Sampling methods and analysis for each variable are also detailed in ${ }^{19}$ For calculations it was used

a. The original model of Carlson; ${ }^{13}$

b. Modification proposed by Toledo in the 1980's, which includes the reactive soluble phosphorus as a variable and diminishes the relative importance of the Secchi disk $;^{20}$

c. The Trophic State Index for reservoirs $\left(\mathrm{TSI}_{\mathrm{Res}}\right)$, which considers only the total phosphorus and chlorophyll $a$ parameters and makes differentiated adjustments for rivers and reservoirs ${ }^{12}$ and

d. Trophic State Index for tropical/subtropical reservoirs $\left(\mathrm{TSI}_{\mathrm{TSR}}\right.$ ) based on correlations between annual geometric means of total phosphorus versus chlorophyll a and chlorophyll a versus Secchi disk depth. ${ }^{14}$

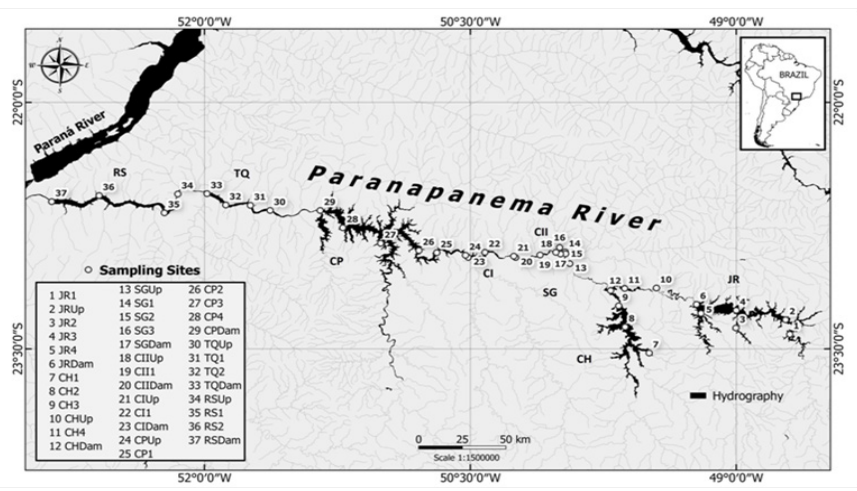

Figure I Geographic location of Paranapanema River reservoir cascade and the selected sampling sites.

Table I Water Quality Index classification

\begin{tabular}{ll}
\hline \multicolumn{2}{l}{ WQI classification } \\
\hline Category & Rating \\
\hline & $79<\mathrm{WQI} \leq 100$ \\
Good & $51<\mathrm{WQI} \leq 79$ \\
Regular & $36<\mathrm{WQI} \leq 5 \mathrm{I}$ \\
Poor & $19<\mathrm{WQI} \leq 36$ \\
Very Poor & WQI $\leq 19$ \\
\hline
\end{tabular}

WQI,Water Quality Index

The classification is in accordance with each method, which has variations in the rating values and categories. Different from the WQI, for the TSI the lower the value the better the water quality (Table 2). To facilitate comparison among the results, equivalent classifications were represented in the same colors. The Phytoplankton Community Index for Reservoirs (FCI) (fitoplâncton in Portuguese) and the Zooplankton Community Index for Reservoirs (ZCI) were both calculated according to ${ }^{12}$ For the FCI Index it is considered the proportion of the main community groups and/or the density of the organisms and the concentration of chlorophyll $a$ or TSI (Chl a). However, the numerically dominant group of phytoplankton in the Paranapanema River reservoir cascade, Cryptophyceae, is not considered by the model. Therefore, for this analysis we used the phytoplankton total density (org. $\mathrm{mL}^{-1}$ ) instead the dominant groups, as well as the Trophic State Index of Carlson modified by Toledo for Chlorophyll $a^{20}$ For the ZCI it is considered the presence of the three main freshwater zooplankton groups (Rotifera, Copepoda and Cladocera), the Calanoida/Cyclopoida ratio and the TSI (Carlson modified by Toledo). ${ }^{20}$ For phytoplankton qualitative analysis, an integrated sample was collected (entire water column) at each sampling station through vertical net hauls $(20 \mu \mathrm{m}$ of mesh size $)$ and immediately preserved in $2 \%$ formalin. The net samples were observed in an optical microscope (maximum magnification of $1000 \times$ ) for taxonomical identification and determination of the assemblage total richness. For phytoplankton quantitative analysis, three unfiltered samples were collected (van Dorn bottle) at the subsurface (ca. $0.2 \mathrm{~m}$ ), middle of the water column and near to the bottom (ca. $1 \mathrm{~m}$ above the sediment). The samples were fixed and preserved with Lugol's solution. After sedimentation, the organisms (cell, colony, and filament) were counted using inverted microscopy (sensu Utermöhl) at a magnification of $400 \times$. At least 120 optical fields distributed in parallel transects were examined, and at least 150 organisms were counted per sample. A mean value for the water column was calculated for further use in the FCI index. The zooplankton samples were collected using a conical net $(30 \mathrm{~cm}$ mouth diameter and $50 \mu \mathrm{m}$ mesh size) for vertical hauls from near bottom (ca. $1 \mathrm{~m}$ ) towards the surface. In each site we collected two identical samples, one for qualitative and the other for quantitative purpose. Samples were fixed and preserved in $4 \%$ formaldehyde. For the quantitative analyses, most organisms were counted at species level. Rotifera, and nauplii of Copepoda were counted in Sedgwick-Rafter chambers, under optic microscope Zeiss Standard 25 (at a magnification of $\times 200$ ); and Cladocera, copepodites and adult stages of Copepoda were counted using a stereo microscope Zeiss Stemi SV 6 (maximum magnification of $\times 120$ ). At least 150 specimens were counted per subsample. Additional sub-samples, or even the entire sample, were analyzed when the density of organisms was low (generally less than 100 organisms per $5 \mathrm{ml}$ of sample, in case of Cladocera and Copepoda, and less than 100 organisms per $1 \mathrm{ml}$ of sample, in case of Rotifera).

Table 2 Classes of Trophic State Index

\begin{tabular}{|c|c|c|c|c|}
\hline TSI classification & $\begin{array}{l}\text { TSI } \\
\text { carlson }\end{array}$ & $\begin{array}{l}\text { TSI carlson } \\
\text { mod. } \\
\text { toledo }\end{array}$ & $\begin{array}{l}\text { TSI } \\
\text { reservoir }\end{array}$ & TSI $_{\text {TSR }}$ \\
\hline \multirow[t]{2}{*}{ Ultraoligotrophic } & $<20$ & & $\mathrm{TSI}<47$ & $\leq 51.1$ \\
\hline & $2|-4|$ & $\mathrm{TSI}<44$ & $\begin{array}{l}47<\mathrm{TSI} \\
\leq 52\end{array}$ & $\begin{array}{l}51.2- \\
53.1\end{array}$ \\
\hline Mesotrophic & $4 I-50$ & $44<\mathrm{TS} \mid>54$ & $\begin{array}{l}52<\mathrm{TSI} \\
\leq 59\end{array}$ & $\begin{array}{l}53.2- \\
55.7\end{array}$ \\
\hline Eutrophic & $51-60$ & TSI $>54$ & $\begin{array}{l}59<\mathrm{TSI} \\
\leq 63\end{array}$ & $\begin{array}{l}55.8- \\
58.1\end{array}$ \\
\hline Supereutrophic & & & $\begin{array}{l}63<\mathrm{TSI} \\
\leq 67\end{array}$ & $\begin{array}{l}58.2- \\
59.0\end{array}$ \\
\hline Hypereutrophic & $>61$ & & TSI $>67$ & $\geq 59.1$ \\
\hline
\end{tabular}

TSI,Trophic State Index 
The Planktonic Index of Biotic Integrity (P-IBI) was calculated according to methodology detailed in ${ }^{19}$ after. ${ }^{6,21}$ As this index is derived from a proposal developed for natural large lakes, ${ }^{6}$ it was only used for the Paranapanema storage reservoirs (water retention time higher than 100 days) (Jurumirim, Chavantes and Capivara). The classification rating was also showed in terms of colors, corresponding to similar categories of the previously mentioned indices. The classes for FCI for reservoirs and P-IBI are presented in Table 3 and for ZCI for reservoirs in Table 4. Lower values of classification correspond to better the water quality. To reinforce the potential of the zooplankton as bioindicator of the water quality and to corroborate the effectiveness of the Zooplankton Community Index for Reservoirs (ZCI) and the Plankton Index of Biotic Integrity (P-IBI), we performed an exploratory analysis using the Pearson correlation (Pearson, $\mathrm{p}<0,05$ ) Statistic v. 7.0.21 The following genera/ species of zooplankton were chosen as indicators of trophic state based on the literature review: Brachionus sp., Collotheca sp. and Filinia sp. among Rotifers; Argyrodiaptomus sp., Notodiaptomus iheringi, Thermocyclops decipiens, and Thermocylops minutus, among the Copepods; and Bosmina sp. and Daphnia sp. among Cladocerans. Additionally, we considered the total abundance and richness of Rotifera, Cladocera and Copepoda (with and without nauplii counts) and the relation Calanoida/Cyclopoida + Cladocera. Zooplankton data were correlated with the limnological variables (transparency, dissolved oxygen, biochemical oxygen demand, conductivity, chlorophyll, total phosphorus, soluble reactive phosphorus, total nitrogen, total suspended solids, organic suspended solids, inorganic suspended solids $)^{19}$ and with the quantitative results of WQI and T.S.I. for reservoirs ${ }^{12}$ and T.S.I. for tropical and subtropical reservoirs. ${ }^{14} \mathrm{We}$ selected some results for graphical presentation. All data, except $\mathrm{pH}$, were log-transformed and the parametric distributions was verified in the software Statistic v. 7.0.22 The selection of zooplankton metrics is based on regional studies carried out in reservoirs with different trophic states..$^{16,23-33}$ For all index calculations we used the variables mean values for the water column, except transparency.

Table $3 \mathrm{PCl}$ for reservoir and P-IBI classifications

\begin{tabular}{lll}
\hline Classification & $\mathbf{F C l}_{\text {Res }}$ & P-IBI \\
\hline Good & 1 & Excellent \\
Regular & 2 & Good \\
Bad & 3 & Fair \\
Very Bad & 4 & Poor \\
\end{tabular}

PCl, Phytoplankton Community Index

Table $4 \mathrm{ZCl}$ for reservoir classifications based on T.S.I. (Chla) and Calanoida/ Cyclopoida ratio

\begin{tabular}{l|llllll}
\hline & 74 & Very Bad & Bad & Bad & Bad \\
T.S.I. (Chla) & 54 & Bad & Regular & Regular & Regular \\
& 44 & Regular & Regular & Good & Regular \\
& 24 & Regular & Good & Good & Good \\
& 0 & Good & Good & Good & Good \\
\cline { 2 - 6 } & & 0,5 & I,0 & 2,0 & \\
\hline & Cal/Cyc & & &
\end{tabular}

ZCI, Zooplankton Community Index

\section{Results}

The Water Quality Index for the Paranapanema River reservoir cascade resulted in only two distinct classifications, Good and Excellent (Table 5). Among the 74 determinations the Excellent condition widely prevailed (64 times) over the Good condition (10 times). The index evidences a decrease in the water quality condition during the wet season. In this period the proportion of sampling stations considered Excellent corresponded to $81.1 \%$ and in the dry season it was $91.9 \%$. Comparison among the different models of Trophic State Index for the Paranapanema River reservoir cascade is shown in Table 6. Lower trophic levels were obtained when used the original Carlson Index. Results ranged from Hypereutrophic (SG1) to Oligotrophic $\left(\mathrm{CH}_{3}, \mathrm{CH}_{4}\right.$ and $\left.\mathrm{CHDam}\right)$ in the wet season and from Hypereutrophic (CP1 and CP2) to Oligotrophic (JR3, JRDam and CHDam) in the dry season. Most sampling sites ( $70.3 \%$ considering both seasons) were classified as Mesotrophic according to this index. The same number (8 times) of higher trophic conditions (Hypereutrophic/Eutrophic) was found in wet and dry seasons. For the Carlson Trophic State Index modified by Toledo, the Eutrophic condition was determined four times (SG1, wet season; CP1, CP2 and RS1, dry season). Other classifications varied between Oligo (71.6 \%) and Mesotrophic (21.6 $\%)$ conditions, during both wet and dry seasons (Table 6). Following the original Carlson Index this model also indicates a decrease in the water quality during the rainy season. The results of the Trophic State Index for Reservoirs were similar to the ones of Carlson modified by Toledo, showing the predominance of Oligotrophic and Mesotrophic conditions, 29.7 and $59.5 \%$ of the determinations, respectively (Table 6). The stations with the best trophic conditions according to this model were JR3, JRDam and CH3, which were classified as Ultraolithotrophic during the dry season when it was detected an improvement of the water quality. The most recent model of Trophic State Index proposed for tropical and subtropical reservoirs indicated predominance of Ultraoligotrophic conditions, corresponding to $77.0 \%$ of the sampling sites (Table 6), followed by Oligotrophic condition $(17.6 \%)$. Only one site during the wet season was classified as Eutrophic (SG1). The use of Phytoplankton Community Index for reservoir resulted in similar proportion of Good and Excellent conditions, 47.3 and $51.3 \%$ of the determinations, respectively (Table 7). Only one Regular condition was detected (SG1, wet season). Differently, for the Zooplankton Community Index (ZCI) the condition Excellent was not determined. Most sites were classified as Good (72.9\%) or Regular (21.6\%) for both seasons (Table 7). The sites SG1 and SG3 were classified as Bad conditions in both wet and dry seasons, according to the ZCI. Both plankton indices were not sensitive to the seasonal variation. The Planktonic Index of Biotic Integrity showed that most sites are in Excellent conditions (75\%) and the others are Good (25\%). Regular, Bad and Very Bad conditions were not detected. Jurumirim reservoir exhibited a higher number of sampled sites with "Good" conditions when compared with the other reservoirs (Table 8). There was no remarkable difference between wet and dry season. Three hundred and ninety-nine correlations among distinct zooplankton metrics and environmental variables as well as with integrated indices were performed. We selected for graphical representation a set of significant correlations $(p<0.05)$ (Figure 2). Some correlations, although significant, were not considered either because its amplitude of variation was not sensitive to capture environmental distinctiveness for the Paranapanema River reservoir cascade (e.g. dissolved oxygen that also exhibited high values) or because the variable (e.g. temperature) is not directly related to the water quality condition. Among the main results it can be mentioned 
the correlation of the rotifers genera Brachionus and Filinia with trophic increase (water quality decrease), while the genus Collotheca exhibited an opposite tendency. For microcrustaceans we observed that Calanoida was correlated with good water quality and low trophic levels as well as for Cladocera, and the opposite, was observed for
Cyclopoida. For lower microcrustacean taxonomic level it can be mention the inverse relationship of T. minutus with total phosphorus and the inverse relationship of Daphnia with TSI mod. Toledo and positive with WQI (Figure 2).

Table 5 WQI classification for Paranapanema River reservoir cascade during the wet and dry season

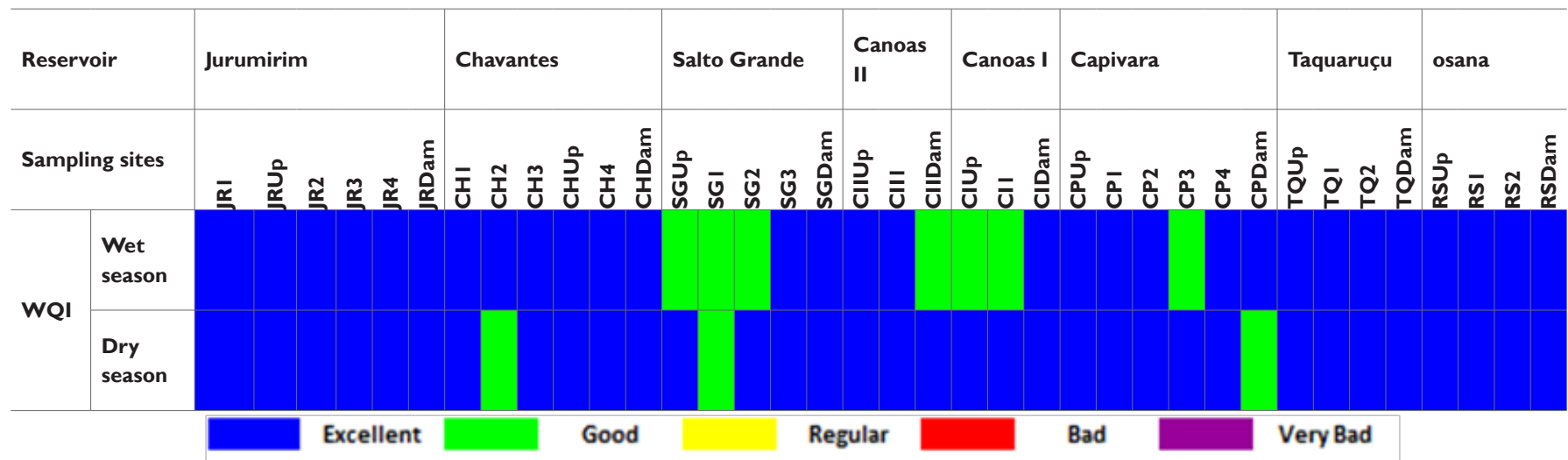

WQI ,Water Quality Index; JR, Jurumirim; CH, Chavantes; SG, Salto Grande; CII , Canoas II; CI, Canoas I; CP, Capivara;TQ ,Taquaruçu; RS, Rosana; UP, Upstream.

Table 6 Comparison of the different Trophic State Index models and respective classification for Paranapanema River reservoir cascade during the wet and dry season

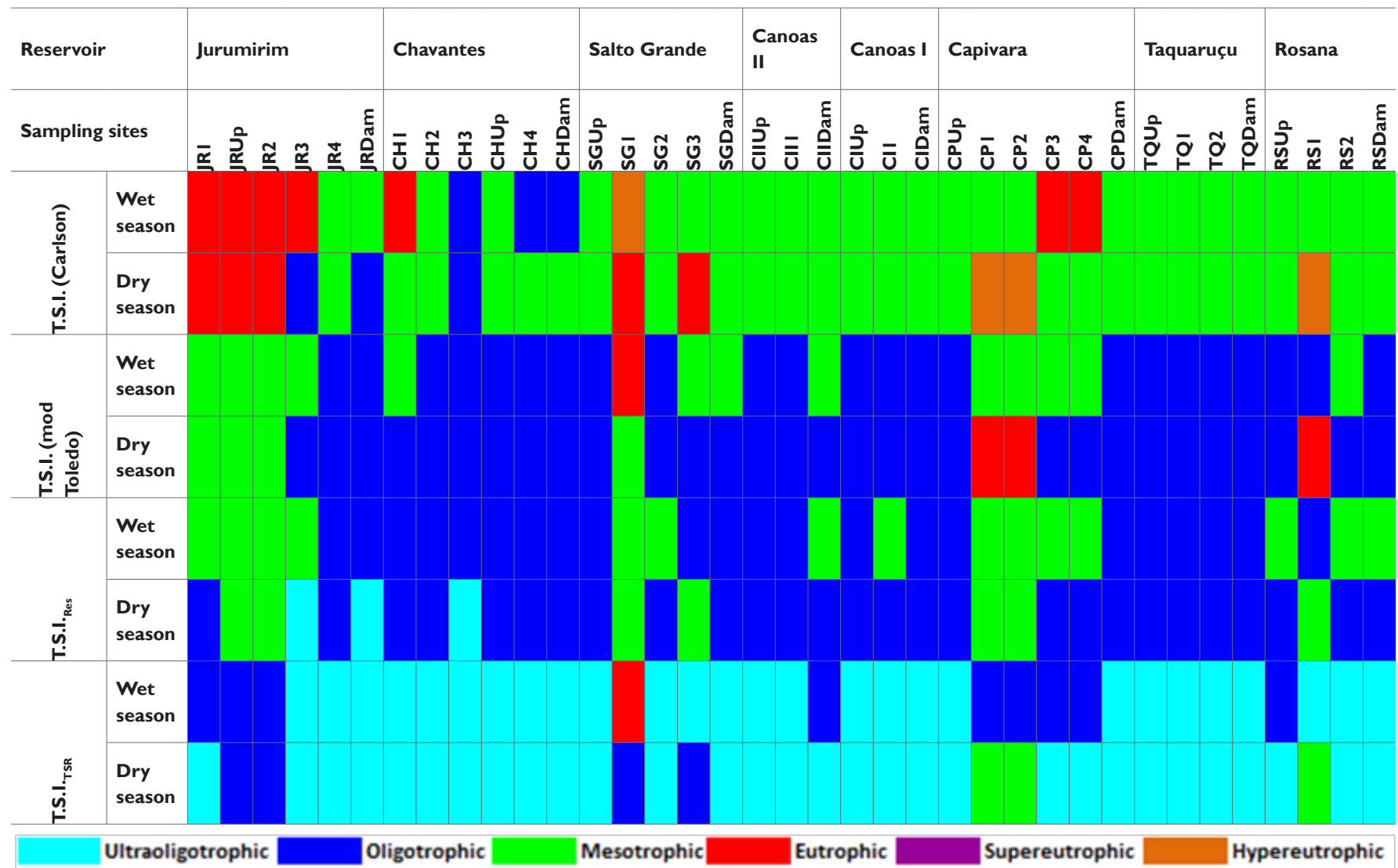

TSI ,Trophic State Index; JR, Jurumirim; CH, Chavantes; SG, Salto Grande; CII , Canoas II; Cl, Canoas I; CP, Capivara;TQ, Taquaruçu; RS, Rosana; UP, Upstream 
Table 7 Comparison between Phytoplankton Community Index (PCl) and Zooplankton Community Index ( $\mathrm{ZCl})$ for reservoirs and respective classification for Paranapanema River reservoir cascade during the wet and dry season

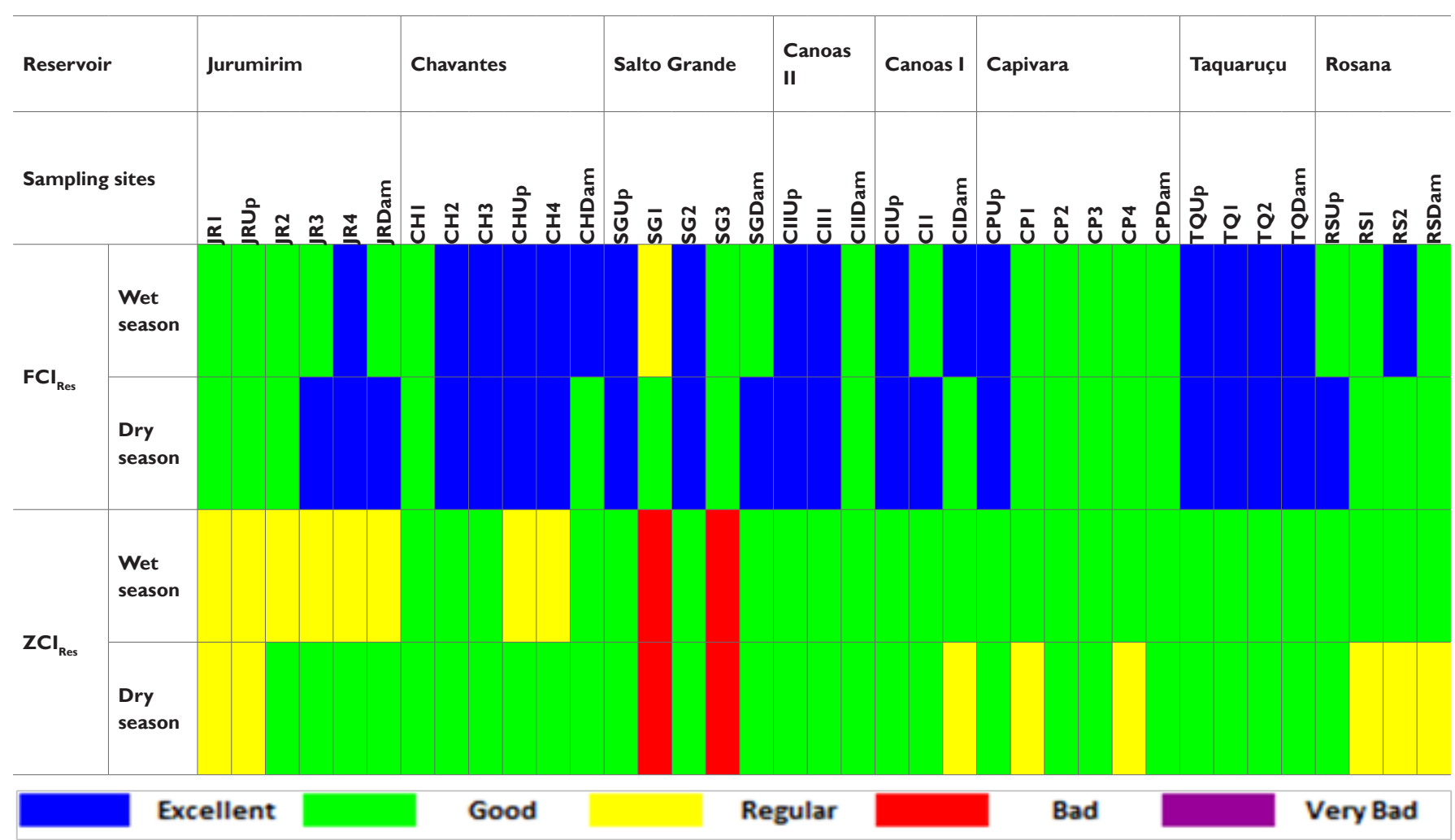

JR, Jurumirim; CH, Chavantes; SG, Salto Grande; Cll, Canoas II; Cl, Canoas I; CP, Capivara;TQ, Taquaruçu; RS, Rosana; UP, Upstream

Table 8 P-IBI classification for selected reservoirs in the Paranapanema River cascade during the wet and dry season

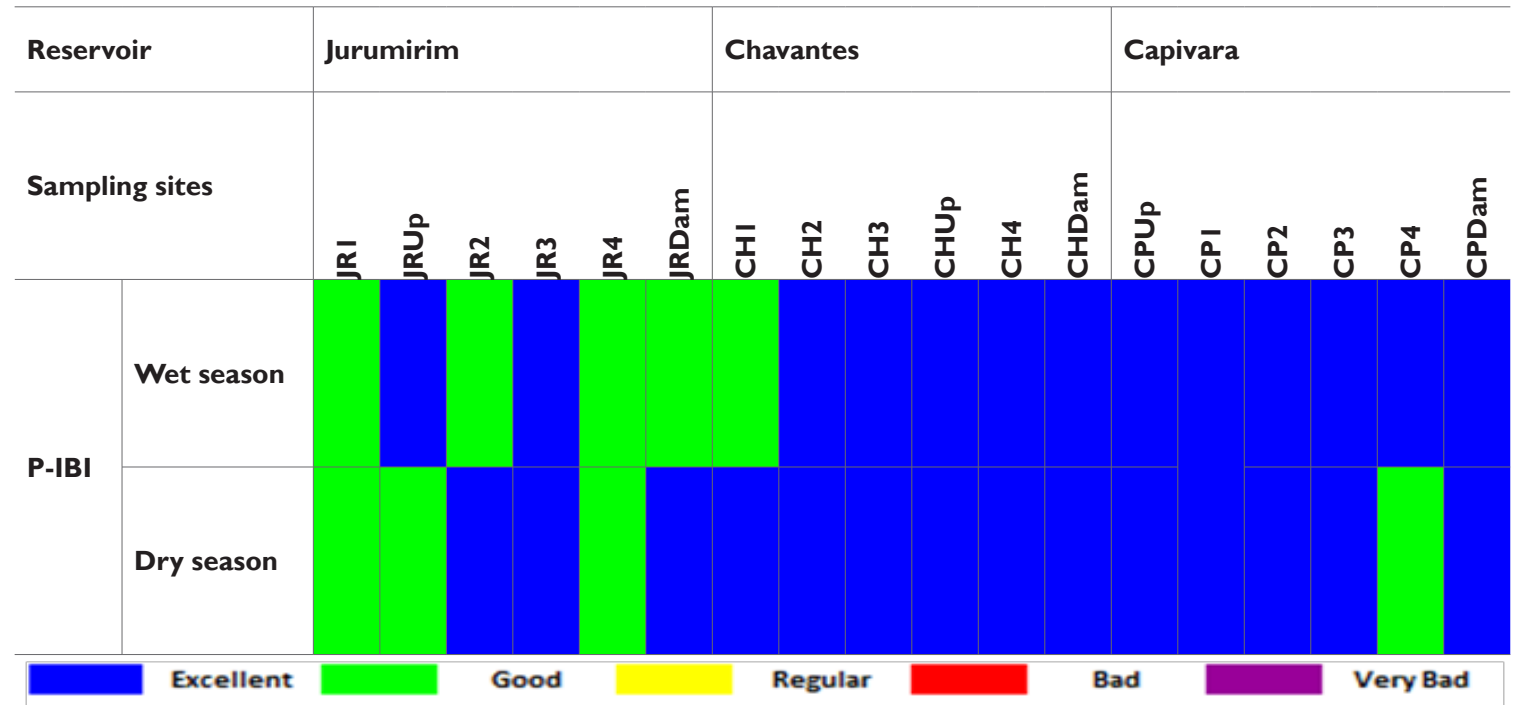

JR, Jurumirim; $\mathrm{CH}$, Chavantes; $\mathrm{CP}$, Capivara; UP, UP 

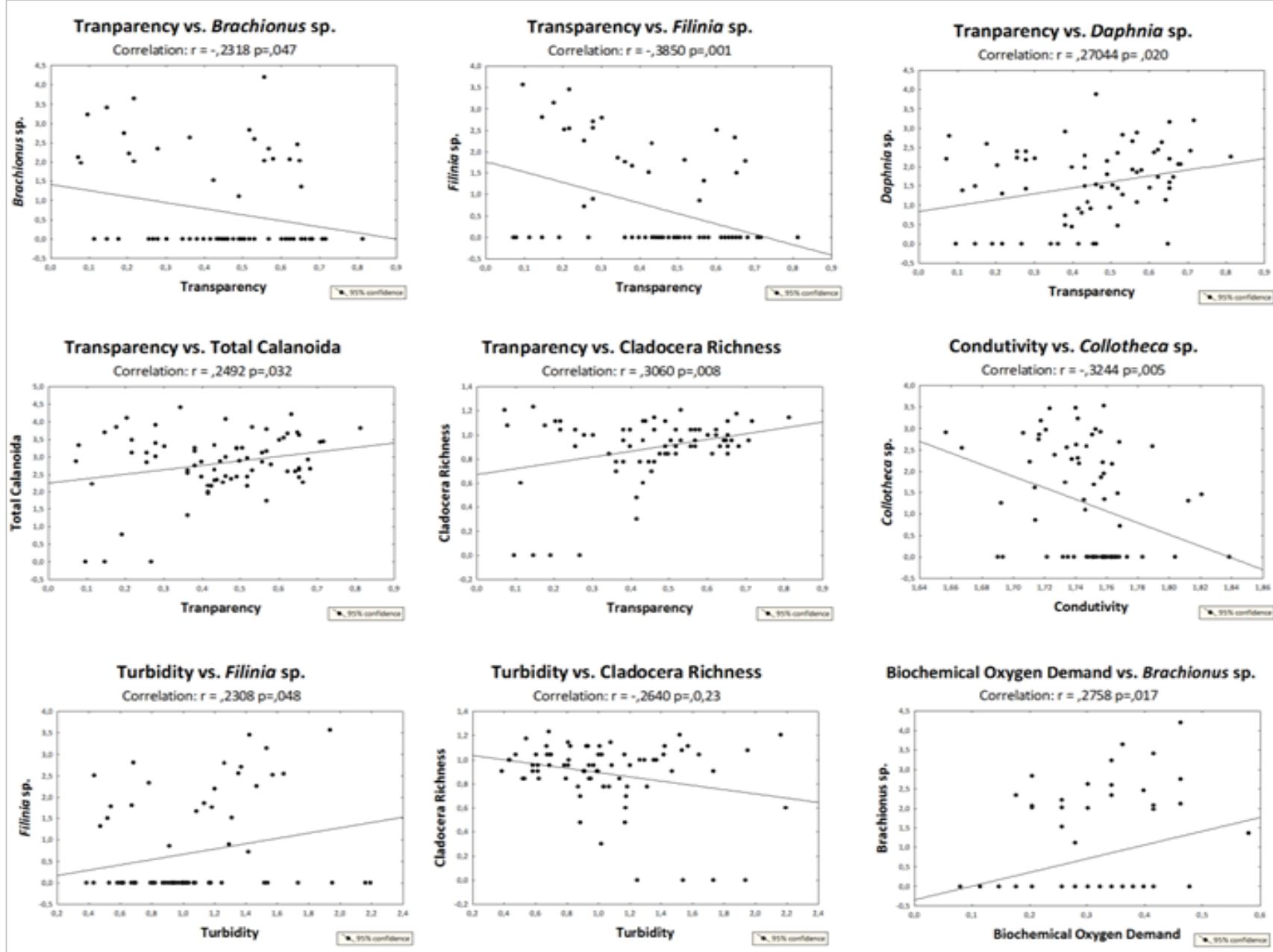

Biochemical Oxygen Demand vs. Brachionus sp.

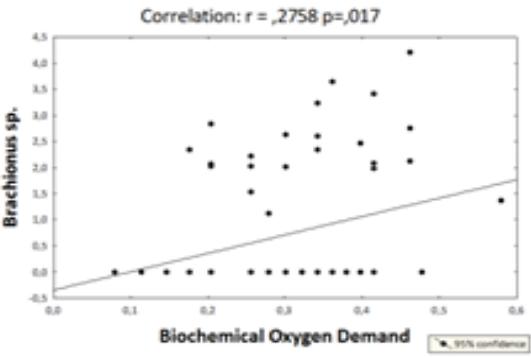

Inorganic Suspended Solids vs. Filinia sp.
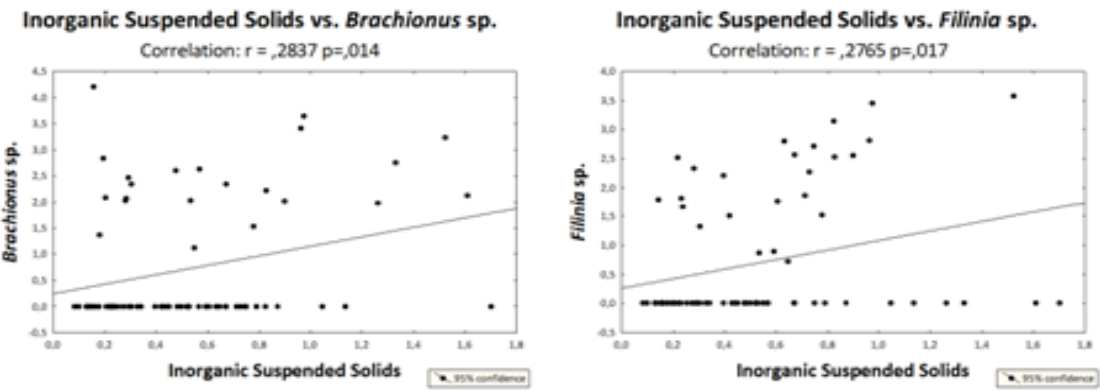

Organic Suspended Solids vs. Filinia sp. Correlation: $r=, 2296 p=, 049$

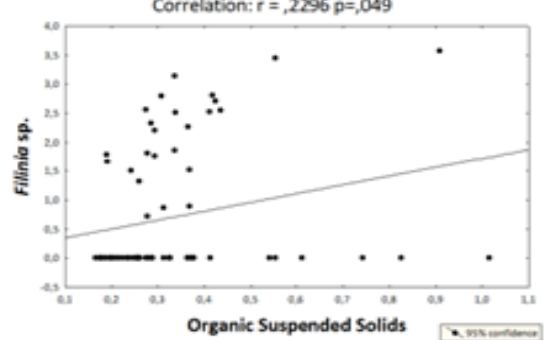

Organic Suspended Solids vs. Calanoida Correlation: $r=-, 3015 p=, 009$

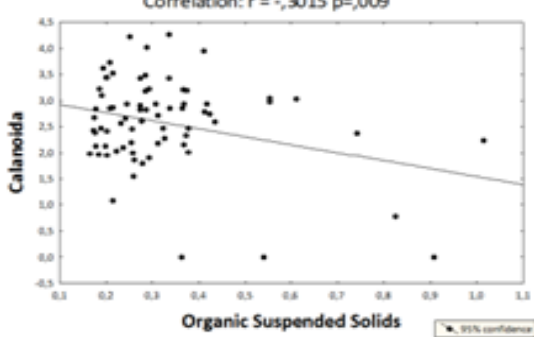

Citation: Pomari J, Kane DD, Nogueira MG.Application of multiple-use indices to assess reservoirs water quality and the use of plankton community data for biomonitoring purposes. Int J Hydro. 20I8;2(2):I68-I79. DOI: I0.15406/ijh.20I8.02.00065 


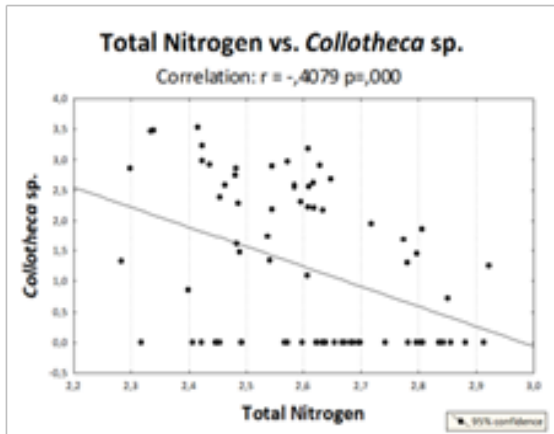

Total Phosphorus vs. Thermocyclops minutus

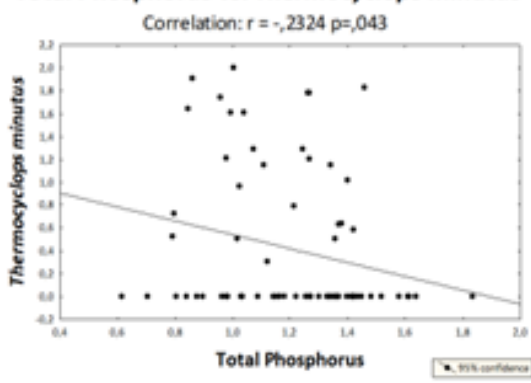

Total Phosphorus vs. Total Cladocera

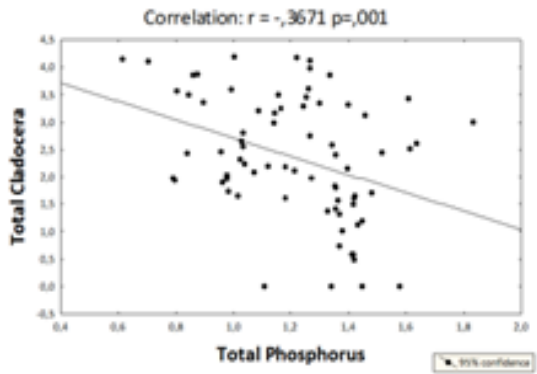

Soluble Reactive Phosphorus vs. Fillinia sp. Correlation: $r=, 3293 p=004$

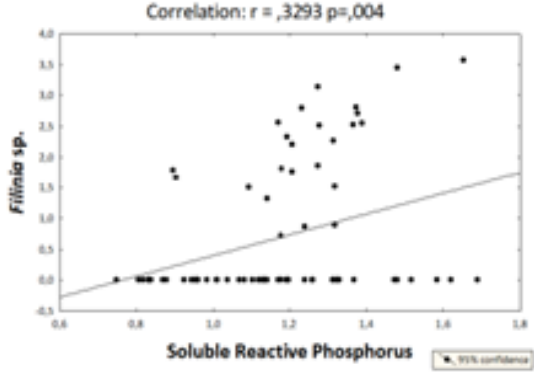

WQI vs. Cladocera Richness

Correlation: $r=, 3078 \mathrm{p}=, 008$

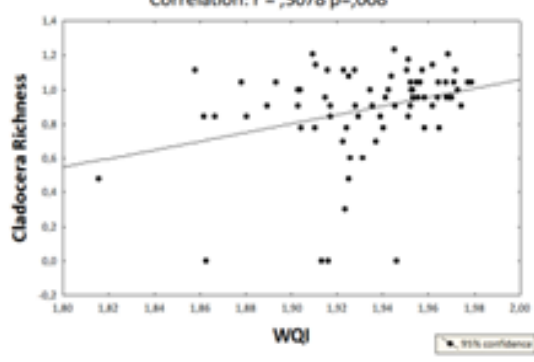

Total Nitrogen vs. Daphnia sp.

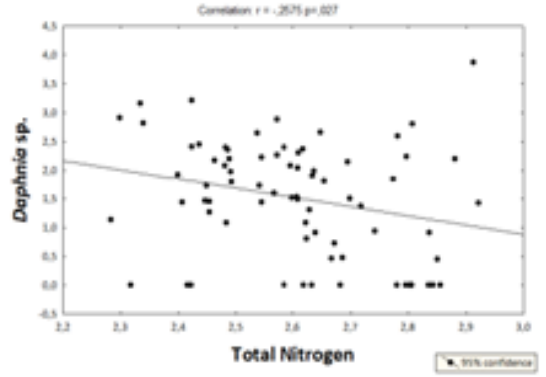

Total phosphorus vs. Daphnia sp. Correlation: $r=s, 4076 p=, 000$

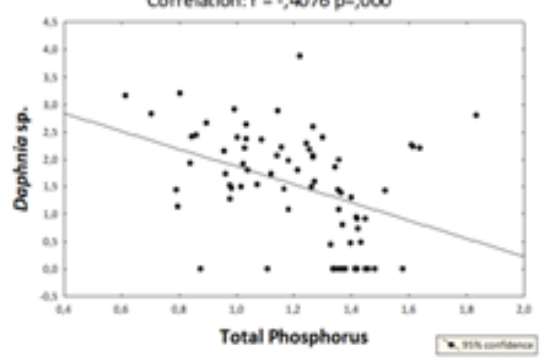

Total Phosphorus vs. Total Calanoida Correlation: $r=-2314 p=0,47$

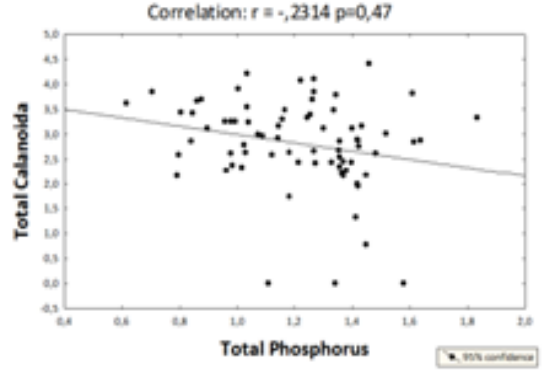

Chlorophill $a$ vs. Brachionus sp. Correlation: $r=, 3819 p=, 001$

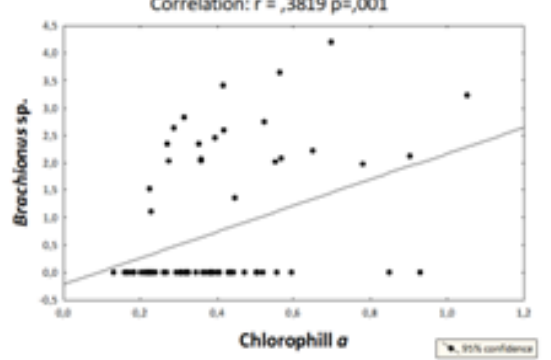

T.S.I (Carlson mod Toledo) vs. Brachionus sp. Correlation: $r=, 2339 p=, 045$

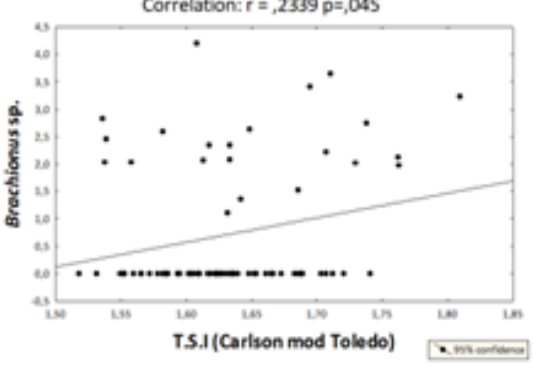

Total Phosphorus vs. Collotheca sp. Correlation: $r$ " -, 3497 pn, 000

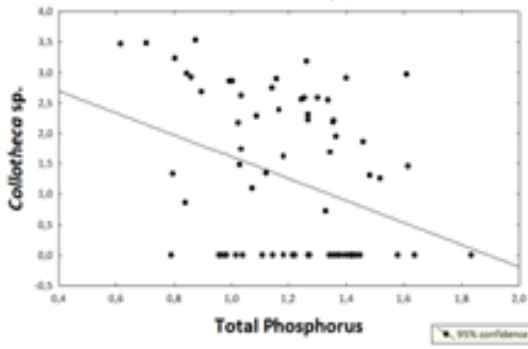

Total Phosphorus vs. Total Rotifera Comelation: $\mathrm{r}=-, 3370 \mathrm{pm}, 003$

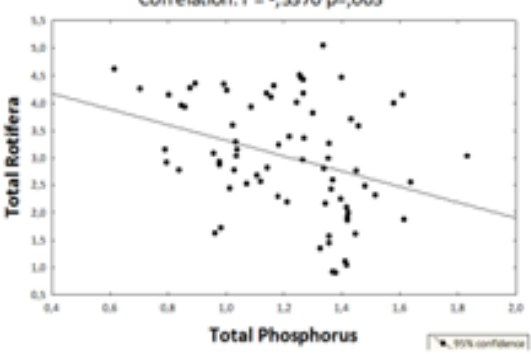

Soluble Reactive Phosphorus vs. Brachionus sp. Correlation: $r=, 2883 p=013$

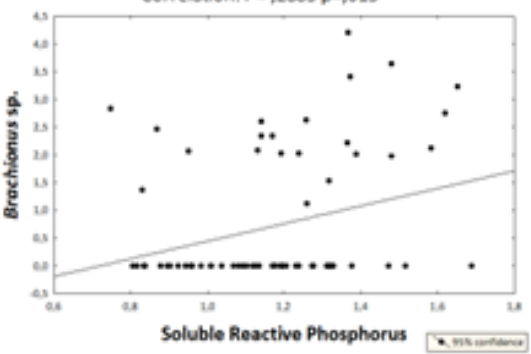

WQI vs. Daphnia sp.

Correlation: $r=, 2954 \mathrm{p}=, 011$

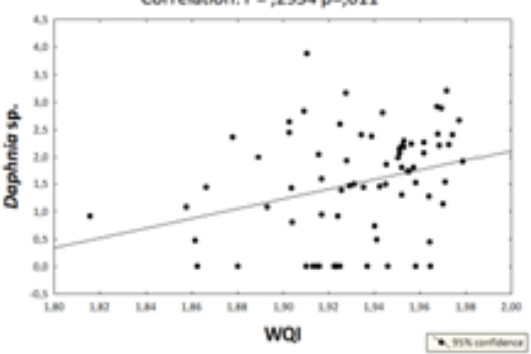

T.S.I (Carslon mod Toledo) vs. Collotheca sp. Correlation: $r=-, 2439 \mathrm{p}=, 036$

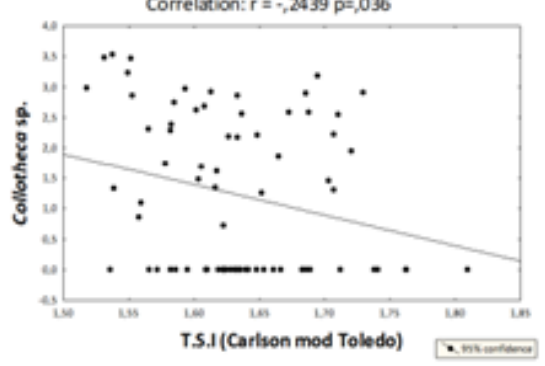

Citation: Pomari J, Kane DD, Nogueira MG.Application of multiple-use indices to assess reservoirs water quality and the use of plankton community data for biomonitoring purposes. Int J Hydro. 20 I8;2(2):I68-I79. DOI: I0.I5406/ijh.20I8.02.00065 


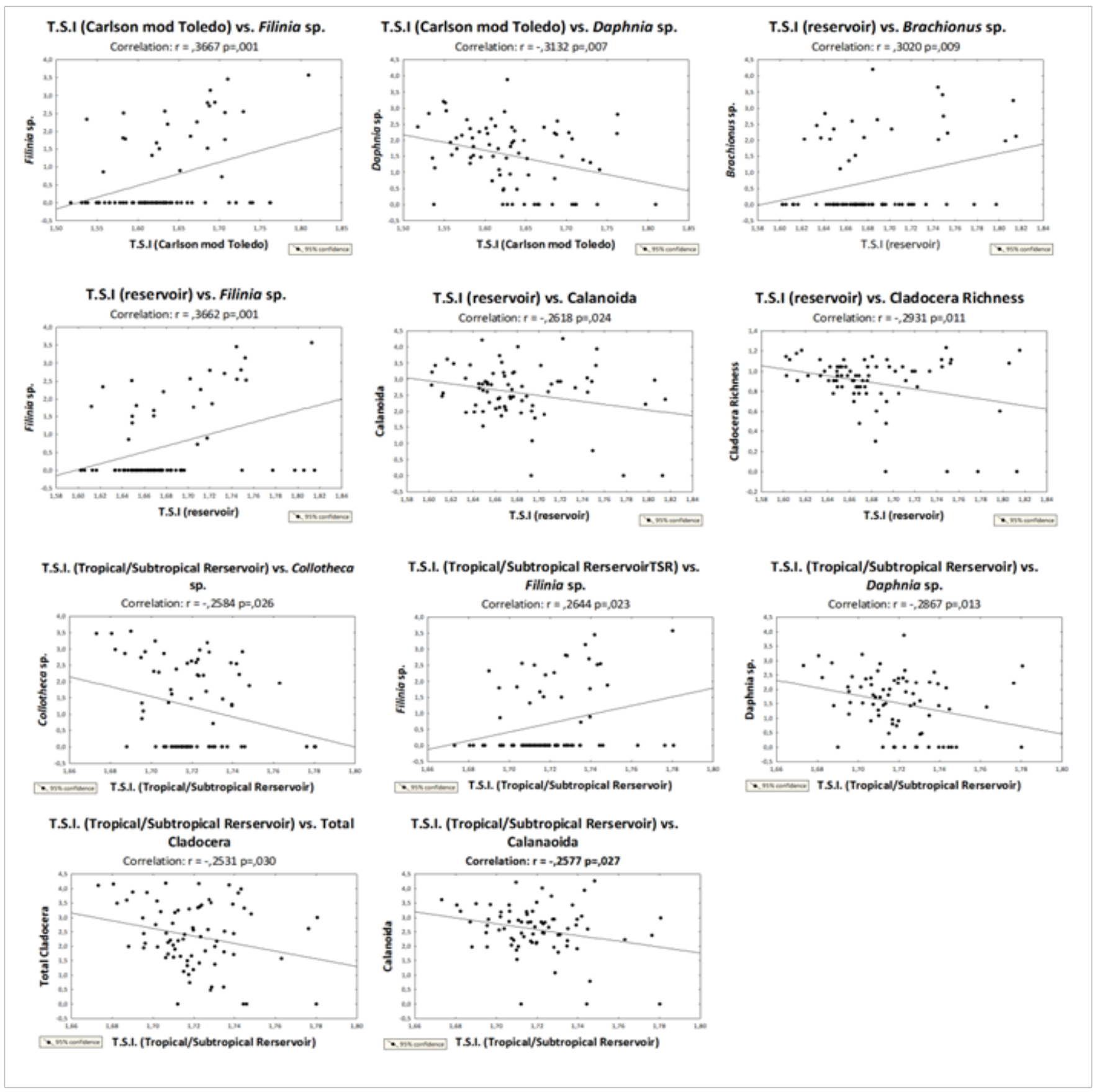

Figure 2 Correlations between zooplankton metrics with limnological variables,WQI and T.S.I. indices.

\section{Discussion}

Different responses were obtained with the application of the distinct water quality/trophic state indices in the Paranapanema River reservoir cascade. For interpretation it is imperative to consider that water quality concept is not absolute; the terms "good" or "poor" water quality have definite meaning only in relation to the intended water use and the assessment of the user. ${ }^{34}$ A crucial point is that the management questions and required information be clearly articulated and understood during selection of appropriate indicators to provide useful information for hydric resources managers. ${ }^{3}$ In this way, the Water Quality Index (WQI) has been regularly used in monitoring programs and it is considered a strong and reliable index once it is composed of physical, chemical and biological variables previously established by experts to detect the quality of water for public supply purposes. Additionally, it is essential that the indices agree with the results described in traditional limnological studies. Environmental evaluation using Trophic State Index (TSI) is more suitable for needs of natural water resources management when eutrophication is a major threat. ${ }^{34}$ Conversely, the WQI allows accounting for several 
water resources uses and therefore it is a more comprehensive tool for water quality quantification. In the last decades we have faced a discussion related to the misuse of the original TSI model proposed by Carlson $^{13}$ for tropical/subtropical regions and regardless of the type of environment system (i.e. lakes, rivers, reservoirs, flooded areas). Originally the Trophic State Index (TSI) was developed for temperate lakes. It integrates information about nutrient (phosphorus), chlorophyll, and transparency (Secchi disk depth). The purpose of the trophic status index is to classify water bodies into different degrees of trophy, that is to assess water quality changes related to nutrient enrichment. Studies have been carried out proposing modifications, or minor adaptations, to better meet the criteria and purposes of this index for a certain habitat or regional characteristics. ${ }^{14,35}$ An important consideration is that temperate and tropical/subtropical aquatic systems have specific sensitivities to eutrophication, ${ }^{36}$ because they are exposed to different magnitude of stressors concerning climatological attributes and land use shifts, with corresponding changes in physical, chemical and biological characteristics of the aquatic ecosystem..$^{37}$ The prediction of trophic state changes may be more complex in tropical/subtropical freshwaters because there are more environmental constraints controlling nutrient dynamics and the phytoplankton responses in such water bodies. ${ }^{14,38}$ The main reason for establishing a specific index for tropical/subtropical regions is that the Carlson's model only considers the highest productive seasons in temperate lakes (spring and summer), whilst tropical/subtropical systems may have high primary production through all the year. ${ }^{14,38}$ The TSIs comparative analyses are easier to be interpreted if one has solid information on the limnological structure and functioning of the considered environment. In case of Paranapanema River reservoir cascade, based on previous limnological information, ${ }^{16-18,24,39}$ we can affirm that the original Carlson model ${ }^{13}$ overestimates the trophic condition - most sampling sites were classified as Mesotrophic or even Eutrophic and Hypereutrophic. The Carlson TSI models modified by Toledo ${ }^{20}$ and by CETESB, ${ }^{12}$ to be applied in reservoir systems, showed to be more appropriated for tropical and subtropical environments. In case of the first modified model around $70 \%$ of the Paranapanema reservoirs determinations resulted in Oligotrophic conditions, followed by Mesotrophic, 27\%. For the second it was around 60 and 30\%, for Oligotrophic and Mesotrophic, respectively. These results are more realistic if considered the predominant low concentrations of total nitrogen (generally lower than $300 \mu \mathrm{g} \mathrm{L}^{-1}$ ), total phosphorus (generally lower than $20 \mu \mathrm{g} \mathrm{L}^{-1}$ ) and total chlorophyll a (exceptionally higher than $3 \mu \mathrm{g} \mathrm{L}^{-1}$ ) commonly found in the Paranapanema reservoirs. ${ }^{16-18,24,39}$ These models were also sensitive to the seasonal changes, capturing the water quality decrease during the rainy season (summer) due to the higher input of sediment and nutrients. A difference to be considered between both modified models is that the first does not consider the type of environment, such as the reservoir ecosystem particularities that are considered in the second. The TSI for tropical/subtropical reservoirs ${ }^{14}$ considers relevant ecological aspects for an appropriate assessment, including geographic positioning (tropical/subtropical region) and it was already tested for a large number of reservoirs of São Paulo State for validation purpose. Most classifications using this model resulted as Ultraoligotrophic (77\%) followed by Oligotrophic (17.6\%) which can be associated with the truly lower concentration of nutrients in the considered reservoir cascade. Seasonality was not detected. Similar results were obtained for WQI, but in this case, seasonality was better captured, resulting Excellent for $70 \%$ of the determinations during the wet season and $95 \%$ in the dry season. The organisms integrate time and space in a more conservative manner than physical and chemical variables and the incorporation of information on aquatic biota into water monitoring programs is a necessary strategy for alignment with the most advanced regulations..$^{40}$ By studying the ecological attributes (presence/absence, richness, abundance, dominance, equitability, taxonomic and functional diversity) of aquatic communities, it is possible to cover the wide range of environmental conditions in the watershed and their potential effects on the aquatic biota. ${ }^{6,40,41}$ In our study, we also tried to use the available information on plankton communities of the Paranapanema reservoir cascade. Based on the application of the phytoplankton and zooplankton communities indices for reservoirs (FCI and ZCI, respectively) proposed by ${ }^{12}$ we can assume that they have a good potential to represent the water quality standards when compared to the already established WQI and TSI indices. The FCI classified the studied sites in only two categories, Excellent (52\%) and Good (48\%). The ZCI resulted to be more sensitive, with $73 \%$ of the determinations as Good, $22 \%$ as Regular and $5 \%$ as Bad. However, it is important to mention that the lack of data and published results from these plankton indices applications, fundamental for comparisons, is a substantial limitation. The Planktonic Index of Biotic Integrity (P-IBI) is a relatively new tool for evaluation of lake "health". ${ }^{6}$ The first Index of Biotic Integrity (IBI) proposed by ${ }^{21}$ recognizes the importance of interactions among five classes of main factors to the aquatic biota: energy, chemical constituents, habitat structure, hydrology, and interactions between organisms. The development and validation of the P-IBI proposal for Paranapanema River large reservoirs (Jurumirim, Chavantes and Capivara) was performed by. ${ }^{19}$ The application of this index resulted in only two categories, Excellent, $75 \%$ of the determinations, and Good, $25 \%$ of the determinations. Results were similar to the FCI classifications and, as observed for the FCI and ZCI indices, the P-IBI was not sensitive to seasonal changes. In addition to the indices application we also tried to improve our understanding on the zooplankton responses to the variability in the water quality and trophic state. The successful use of the zooplankton community as a potential bioindicator of environmental quality in freshwaters has been reported by limnologists, ${ }^{42,43}$ especially based on the ecological attributes of the community (richness, abundance, dominance, diversity). The association of species to more eutrophic or more oligotrophic environments of the Paranapanema basin has already been analyzed. ${ }^{16,32}$ The zooplankton abundance (generally dominated by few species) is positively correlated to high values of chlorophyll and nutrients (especially $\mathrm{N}$ and $\mathrm{P}$ ) and negatively to conductivity and dissolved oxygen. ${ }^{32}$ Besides these general trends, individual responses of the species are still little known but would be desirable to simplify biomonitoring schemes by using a smaller number of species with the best response to eutrophication processes.

\section{Conclusion}

The simultaneous application and comparison of distinct water quality and trophic state indices (WQI, TSI and TSI modifications, FCI, ZCI and P-IBI) is a new approach for Paranapanema River reservoir cascade. The WQI ranged from "Good" to "Excellent" in agreement with previous limnological studies (predominantly low nutrients and chlorophyll values) and also indicated the seasonal dryrain patterns. The original Carlson index overestimated the trophic levels while the modified indices for reservoirs seemed to be more suitable for tropical and subtropical environments, especially the one for tropical/subtropical reservoirs which was more sensitive to data variability. 
The potential of using integrated plankton indices, mainly zooplankton metrics, as good environmental indicators was also demonstrated. For some models (FCI, ZCI, P-IBI) would be challenging to incorporate a higher volume of data set to confirm/ validate the observed trends. Results of the study can be promptly considered for the improvement of the water quality monitoring program and protocols that have been used in the Paranapanema River basin, Southeast Brazil. Integrated indices, when properly selected, provide valuable insight for complex environmental diagnoses and can support the management-decision processes and get impartial communication to the public. However, indicators are based on simplifications and prudent choices must be tested and validated.

\section{Acknowledgements}

The authors are grateful to Duke Energy International and FUNDIBIO (Foundation of the Biosciences Institute - State University of São Paulo) for financial support (contract 0100015003) and to graduate and undergraduate students of the Laboratory of Continental Waters Ecology (Biosciences Institute - State University of São Paulo) for their help in the field work and laboratory analyses.

\section{Conflict of interest}

None.

\section{References}

1. Tundisi JG, Matsumura TT. Integration of research and management in optimizing multiple uses of reservoirs: the experience of South American and Brazilian cases studies. Hydrobiologia. 2003;500(1-3):231-242

2. Dale VH, Beyeler SC. Challenges in the development and use of ecological indicators. Ecological indicators. 2001;1(1):3-10.

3. Thornton KW, Kennedy RH. Water quality indicators for reservoirs: Proceedings of a workshop. Water Quality Technical Notes Collection (WQTN MS-04), US Army Engineer Research and Development Center, Vicksburg, MS. 1999.

4. Wetzel RG. Limnology of Lake and River Ecosystems. $3^{\text {rd }}$ edition. San Diego: Academic Press; 2001.

5. Abbasi T, Abbasi A. Water Quality Indices. Oxford: Elsevier; 2002.

6. Kane DD, Gordon SI, Munawar M, et al. The Planktonic index of biotic integrity (P-IBI): An approach for assessing lake ecosystem health. Ecological Indicators. 2009;9(6):1234-1247.

7. Katyal D. Water Quality Indices Used for Surface Water Vulnerability Assessment. International Journal of Environmental Sciences. 2011;2(1):154-173.

8. Pesce S, Wunderlin DA. Use of water quality indices to verify the impact of Córdoba City (Argentina) on Suquía River. Water Research. 2000;34(11):2915-2966.

9. Srebotnjaka T, Carr G, Sherbininc A, et al. A global Water Quality Index and hot-deck imputation of missing data. Ecol Indicat. 2012;17:108119.

10. Raican SM, Wang YG, Harch B. Water Quality Indices from Unbalanced Spatio-Temporal Monitoring Designs. In: Wang YG, editor. Water Quality: Indicators, Human Impact and Environmental Health. Inc, New York: Nova Science Publishers; 2013. p. 1-30.

11. BRASIL. Resolução CONAMA no 357, de 17 de março de 2005. Diário Oficial da União [da] República Federativa do Brasil, Poder Executivo, Brasília, DF, 18 de mar. 2005.
12. CETESB - Companhia de Tecnologia de Saneamento Ambiental. Desenvolvimento de índices biológicos para o biomonitoramento em reservatórios do Estado de São Paulo. 2006. p. 58.

13. Carlson RE. A trophic state index for lakes. Limnology and Oceanography. 1977;22(2):361-369.

14. Cunha DGF, Calijuri MDC, Lamparelli MC. A trophic state index for tropical/subtropical reservoirs. Ecological Engineering. 2013;60:126-134.

15. SÃO PAULO (Estado). Resolução SMA-65 de 13 de Agosto de 1998 Diário Oficial [do] Estado de São Paulo, São Paulo, SP, 14 ago. 1998;12.

16. Nogueira MG, Reis OPC, Britto YT. Zooplankton assemblages (Copepoda and Cladocera) in a cascade of reservoirs of a large tropical river (SE Brazil). Limnetica. 2008;27(1):151-70.

17. Nogueira MG, Ferrareze M, Moreira ML, et al. Phytoplankton assemblages in a reservoir cascade of a large tropical - subtropical river (SE, Brazil). Brazilian Journal of Biology. 2010;70(3):7813.

18. Nogueira MG, Perbiche NG, Naliato DAO. Limnology of two contrasting hydroelectric reservoirs (Storage and Run-of-River) in southeast Brazil. In: Samadi BH, editor. Hydropower-Practice and Application. 2012;168-184.

19. Pomari J. Evaluation to the use of water quality indexes and bioindicators: zooplankton and phytoplankton, in a monitoring program of Paranapanema River Reservoir Cascade (SP / PR - Brazil). PhD Thesis. IBB/UNESP/Botucatu; 2017. p. 163.

20. Mercante CTJ, Tucci MA. Comparação entre os índices de Carlson e de Carlson modificado aplicados a dois ambientes aquáticos subtropicais, São Paulo, SP. Acta Limnologica Brasiliensia. 1999;11(1):1-14.

21. Karr JR, Fausch KD, Angermeier PL, et al. Assessing biological integrity in running waters: a method and its rationale. Illinois Natural History Survey Special Publication. 1986;5:1-28.

22. StatSoft Inc. Statistica (data analysis software system). Version 7.0. 2004.

23. Sendacz S, Kubo E, Cestarolli MA. Limnologia de reservatórios do sudeste do Estado de São Paulo, Brasil. VIII. Zooplâncton Bolm Inst Pesca. 1985;12:187-207.

24. Panarelli EA, Nogueira MG, Henry R. Short-Term variability of copepoda abundance in Jurumirim reservoir, São Paulo, Brazil. Braz $J$ Biol. 2001;61:577-598.

25. Nogueira MG. Zooplankton composition, dominance and abundance as indicators of environmental compartimentalization in Jurumirim Reservoir (Paranapanema River), São Paulo, Brazil. Hydrobiologia. 2001;455:1-18.

26. Sampaio EV, Matsumura TT, Rocha O. Composition and abundance of zooplankton in the limnetic zone of seven reservoirs of the Paranapanema River, Brazil. Braz J Biol. 2002;62:525-545.

27. Matsumura T T, Tundisi JG. Calanoida (Copepoda) species composition changes in the reservoir of São Paulo State (Brazil) in the last twenty years. Hydrobiologia. 2003;504:215-222.

28. Casanova SMC, Henry R. Longitudinal distribution of Copepoda populations in the transition zone of Paranapanema River and Jurumirim Reservoir (São Paulo, Brazil) and interchange with two lateral lakes. Brazilian Journal of Biology. 2004;64:11-26.

29. Lansac TFA, Velho LFM, Perenha MCZ, et al. Abundance of Planktonic Ciliates in Cascading Reservoirs of the Paranapanema River, Brazil. Acta Scientiarum Biological Sciences. 2004;26:407-413. 
30. Landa GG, Barbosa FAR, Rietzler AC, et al. Thermocyclops decipiens (Kiefer, 1929) (Copepoda, Cyclopoida) as indicator of water quality in the state of Minas Gerais, Brazil. Braz Arch Biol Technol. 2007;50(4):695705 .

31. Sartori LP, Nogueira MG, Henry R, et al. Zooplankton fluctuations in Jurumirim Reservoir (São Paulo, Brazil): a three-year study. Brazilian Journal of Biology. 2009;69(1):1-18.

32. Perbiche NG, Nogueira MG. Multi-dimensional effects on Cladoceran (Crustacea, Anomopoda) assemblages in two cascade reservoirs in Southeast Brazil. Lakes and Reservoirs: Research and Management. 2010;15:139-152.

33. Perbiche NG, Saito VS, Previattelli D, et al. Cyclopoid copepods as bioindicators of eutrophication in reservoirs: Do patterns hold for large spatial extents? Ecological Indicators. 2016;70:340-347.

34. Parparov A, Gal G, Hamilton D, et al. Water quality assessment, trophic classification and water resources management. Journal of Water Resource and Protection. 2010;2(10):907-915.

35. Zagatto PA, Lorenzetti ML, Lamparelli MC, et al. Aperfeiçoamento de um índice de qualidade de águas. Acta Limnol Bras. 1999;11(2):111-126.

36. Huszar VLM, Caraco NF, Roland F. Nutrient-chlorophyll relationships in tropical-subtropical lakes: do temperate models fit? Biogeochemistry. 2006;79(1-2):239-250.
37. Ortiz JMA, Anda J, Maniak U. Estimation of trophic states in warm tropical lakes and reservoirs of Latin America by using GPSS simulation. Interciencia. 2006;31(5):345-350.

38. Calijuri MC, Santos ACA. Temporal variations in phytoplankton primary production in a tropical reservoir (Barra Bonita, SP-Brazil). Hydrobiologia. 2001;445(1):11-26.

39. Perbiche NG, Ferreira RAR, Nogueira MG. Phytoplankton structure in two contrasting cascade reservoirs (Paranapanema River, Southeast Brazil). Biologia Section Botany. 2011;66(6):967-976.

40. Karr JR. Seven Foundations of Biological Monitoring and Assessment. Biologia Ambientale. 2006;20(2):7-18.

41. Bonada N, Prat N, Resh VH, et al. Developments in aquatic insect biomonitoring: a comparative analysis of recent approaches. Annual Review of Entomology. 2006;51:495-523.

42. Pace ML, Orcutt Jr JD. The relative importance of protozoans, rotifers and crustaceans in a freshwater zooplankton community. Limnology and Oceanography. 1981;26:822-830.

43. Ferdous Z, Muktadir AKM. Potentiality of Zooplankton as Bioindicator. American Journal of Applied Science. 2009;6(10):1815-1819. 